8. Massoud SN, Hunter JB, Holdsworth BJ, Wallace WA, Juliusson R. Early femoral loosening in one design of cemented hip replacement. J Bone Joint Surg [Br] 1997;79-B:603-8.

9. Medical Devices Agency. Hazard notice. HN9801, February 1998.

10. Murray DW, Carr AJ, Bulstrode CJ. Which primary total hip replacement? J Bone Joint Surg [Br] 1995;77-B:520-7.

11. Fowler JL, Gie GA, Lee AJC, Ling RSM. Experience with the Exeter total hip replacement since 1970. Orthop Clin North Am 1988; $19: 477-89$.

12. Howie DW, Middleton RG, Costi K. Loosening of matt and polished cemented femoral stems. J Bone Joint Surg [Br] 1998;80-B:573-6.
13. Kärrholm J, Borssèn B, Löwnhielm $\mathbf{G}$, Snorrason $\mathbf{F}$. Does early micromotion of femoral stem prostheses matter?: 4-7 year stereoradiographic follow-up of 84 cemented hip prostheses. J Bone Joint Surg [Br] 1994;76-B:912-7.

14. Walker PS, Mai SF, Cobb AG, Bentley G, Hua J. Prediction of clinical outcome of THR from migration measurements on standard radiographs: a study of cemented Charnley and Stanmore femoral stems. J Bone Joint Surg [Br] 1995;77-B:705-14.

15. Fender D, Harper WM, Thompson JR, Gregg PJ. Mortality and fatal pulmonary embolism after primary total hip replacement: results from a regional hip register. J Bone Joint Surg [Br] 1997;79-B:896-9.

16. Fender D, Harper WM, Gregg PJ. Need for a national arthroplasty register: funding is important. BMJ 1996;313(7063):1007.

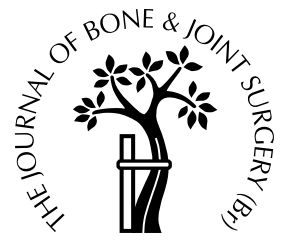

Editorial

\title{
NEONATAL DETECTION OF DEVELOPMENTAL DYSPLASIA OF THE HIP (DDH)
}

\author{
David Jones
}

Thirty years after the introduction of a national screening programme for congenital dislocation of the hip $(\mathrm{CDH})^{1}$ and 12 years after the publication of guidelines, ${ }^{2}$ neonatal clinical examination is failing in its objectives and we are uncertain as to how best to proceed.

The spectrum of presentation of what is now termed developmental dysplasia of the hip (DDH) is wide. It includes neonatal instability, an infant with limited abduction, a limping toddler, a child or adolescent with painful dysplasia and an adult with osteoarthritis. There is general agreement that the earlier the diagnosis the better the outcome and that neonatal examination has been a cornerstone of our management of DDH.

The initial optimism, however, that early clinical examination would eliminate late presentation after three months has long since faded. ${ }^{3-7}$ Over the years, a list of failures of the technique has steadily accumulated. ${ }^{8-15}$ In particular, the experience of the Mälmo group is sobering. ${ }^{8}$ In the hands of these pioneers of clinical screening the incidence of later presentation has risen.

Nevertheless, there is evidence that well-conducted neonatal clinical examination can favourably influence rates of late presentation, especially when performed by expert examiners. $9,16-18$

David Jones, FRCS, FRCS Ed(Orth), Consultant Orthopaedic Surgeon Hospital for Sick Children, Great Ormond Street, London WC1N 3JH, UK.

(C)1998 British Editorial Society of Bone and Joint Surgery 0301-620X/98/69525 \$2.00

J Bone Joint Surg [Br] 1998;80-B:943-5.

VOL. 80-B, No. 6, NOVEMBER 1998
Ultimately, however, we have a clinical test which has a high specificity $(100 \%)$ because there are no false-positive results, but a low sensitivity, probably less than $60 \%$. $^{9,19}$ This is why we need to continue surveillance throughout infancy.

Ultrasound examination either by static or dynamic means is now well established and its role and influence have spread widely. ${ }^{20-25}$ It offers specificity and sensitivity in excess of $90 \%,{ }^{19}$ but it is not infallible. The images can be difficult to interpret, it overdiagnoses the condition, it does not tell us whom to treat and it poses logistical problems in organisation. Opinion is divided among those supporting universal screening as being effective $e^{23,26}$ and those favouring selective use when there is clinical suspicion or in babies at risk because of family history, a foot deformity, breech presentation or torticollis. ${ }^{27,28}$ Others are firmly against universal screening by ultrasound. ${ }^{29-31}$

Universal ultrasound examination requires a national policy with guidelines, the establishment of centres to train screeners and interpreters, agreement on whom should be treated and a long-term outcome study. If a selective policy is adopted we must accept that there will continue to be children who are diagnosed late. ${ }^{32}$

This year the Medical Research Council (MRC) Report on Congenital Dislocation of the $\mathrm{Hip}^{33}$ concluded that neonatal clinical examination had not reduced the incidence of late presentation requiring a surgical procedure, defined as one requiring a general anaesthetic, including an arthrogram or application of a cast, not necessarily a major open operation. It stated that the scientific basis for the screening programme was weak and advised a formal evaluation of current and alternative policies, including 
universal primary ultrasound imaging.

The Report was followed by a statement in the British Medical Journal that clinical screening was not effective and asked if it was justified. ${ }^{34}$ Unfortunately, examiners may be inexperienced and poorly taught. The condition is relatively rare for the individual doctor who is also faced with other problems as part of multiphasic screening. This emphasises the need for orthopaedic surgeons to be active in screening. Our performance as teachers or leaders in such programmes is patchy. ${ }^{35}$

While acknowledging the conclusions of the MRC Report we must be strongly represented in the wider debate. DDH is a disabling condition and we must stress the importance and value of early diagnosis. ${ }^{16-19,25,36}$ We should not allow confusion at the neonatal stage to divert attention from continuing vigilance during infancy for risk factors and later signs of abnormality, especially limited abduction and limb asymmetry. Primary health-care teams must therefore be supported and encouraged.

We should consider a change of terminology. Just as we prefer the term DDH to $\mathrm{CDH}$ because it better describes the condition, it would be more appropriate to use the word 'surveillance' rather than 'screening' when discussing diagnosis. The early detection of DDH does not fulfil the criteria of a screening technique. ${ }^{37,38}$ Although the condition is recognised as an important problem we do not understand the natural history, we do not have a test of sufficient specificity and sensitivity, simple to apply and interpret and agreed by all, we do not have universal agreement on early treatment and the economic consequences are not fully appreciated. ${ }^{39}$

DDH remains mysterious, protean and unsolved. It is poorly understood by those who are largely responsible for detecting it. Current methods of surveillance are fallible and this must be understood in the clinical and medicolegal arenas. In spite of intense dedication over the years and an awesome literature on the subject we have not yet reached a position where we can confidently agree on an acceptable standard of practice. We need a reasoned appraisal of the various methods of surveillance which are available so that a common view can be agreed for the management of this condition.

\section{References}

1. Standing Medical Advisory Committee. Screening for the detection of congenital dislocation of the hip in infants. London: Dept of Health and Social Security, 1969.

2. Standing Medical Advisory Committee and Standing Nursing and Midwifery Advisory Committee. Screening for the detection for congenital dislocation of the hip. London: Dept of Health and Social Security, 1986.

3. Von Rosen S. Diagnosis and treatment of congenital dislocation of the hip joint in the newborn. J Bone Joint Surg [Br] 1962;44-B:284-91.

4. Von Rosen S. Further experience with congenital dislocation of the hip in the newborn. J Bone Joint Surg [Br] 1968;50-B:538-41.

5. Barlow TG. Early diagnosis and treatment of congenital dislocation of the hip. J Bone Joint Surg [Br] 1962;44-B:292-301.
6. Hiertonn T, James U. Congenital dislocation of the hip. $J$ Bone Joint Surg [Br] 1968;50-B:542-5.

7. Finlay HVL, Maudsley RH, Busfield PI. Dislocatable hip and dislocated hip in the newborn infant. Br Med $J$ 1967;4:377-81.

8. Sanfridson J, Redlund-Johnell I, Udén A. Why is congenital dislocation of the hip still missed? Analysis of 96,891 infants screened in Malmö 1956-1987. Acta Orthop Scand 1991;62:87-91.

9. Jones D. An assessment of the value of examination of the hip in the newborn. J Bone Joint Surg [Br] 1977;59-B:318-22.

10. Place MJ, Parkin DM, Fitton JM. Effectiveness of neonatal screening for congenital dislocation of the hip. Lancet 1978;2:249-50.

11. Owen R. Congenital hip dislocation. Br Med J 1971;3:370-1.

12. Walker G. Problems in the early recognition of congenital hip dislocation. Br Med J 1971;3:147-8.

13. Bjerkreim I. Congenital dislocation of the hip joint in Norway. Acta Orthop Scand 1974;Suppl 157.

14. Williamson J. Difficulties of early diagnosis and treatment of congenital dislocation of the hip in Northern Ireland. J Bone Joint Surg [Br] 1972;54-B:13-7.

15. David TJ, Parris MR, Poyner MU, et al. Reasons for late detection of hip dislocation in childhood. Lancet 1983;I:147-9.

16. Dunn PM, Evans RE, Thearle MJ, et al. Congenital dislocation of the hip: early and late diagnosis and management compared. Arch Dis Child 1985;60:407-14.

17. Macnicol MF. Results of a 25-year screening programme for neonatal hip instability. J Bone Joint Surg [Br] 1990;72-B:1057-60.

18. Klisic P, Pajic D. Progress in the preventative approach to developmental dysplasia of the hip. J Paediatr Orthop 1993;Part B, Vol 2:108-11.

19. Rosenberg N, Bialik V, Norman D, Blazer S. The importance of combined clinical and sonographic examination of instability of the neonatal hip. International Orthopaedics 1998:431-4.

20. Graf R. The diagnosis of congenital hip-joint dislocation by the ultrasonic compound treatment. Arch Orthop Trauma Surg 1980;97: 117-33.

21. Harcke HT, Clarke NMP, Lee MS, Borns PF, MacEwen GD. Examination of the infant hip with real-time ultrasonography. J Ultrasound Med 1984;4:131-7.

22. Berman L, Klenerman L. Ultrasound screening for hip abnormalities: preliminary findings in 1001 neonates. Br Med J 1986;293: 719-22.

23. Graf R, Tschauner C, Klapsch W. Progress in prevention of late developmental dislocation of the hip by sonographic newborn hip 'screening': report of a comparative follow-up study. J Paediatr Orthop 1993;Part B, Vol 2:115-21.

24. Clarke NMP, Harcke HT, McHugh P, et al. Real-time ultrasound in the diagnosis of congenital dislocation and dysplasia of the hip. $J$ Bone Joint Surg [Br] 1985;67-B:406-12.

25. Dezateux C, Godward S. A national survey of screening for congenital dislocation of the hip. Arch Dis Child 1996;74:445-8.

26. Marks DS, Clegg J, Al-Chalabi AN. Routine ultrasound screening for neonatal hip instability: can it abolish late-presenting congenital dislocation of the hip? J Bone Joint Surg [Br] 1994;76-B:534-8.

27. Jones DA, Powell N. Ultrasound and neonatal hip screening: a prospective study of 'high risk' babies. J Bone Joint Surg [Br] 1990; 72-B:457-9.

28. Boeree NR, Clarke NMP. Ultrasound imaging and secondary screening for congenital dislocation of the hip. J Bone Joint Surg [Br] 1994; 76-B:525-33.

29. Castelein RM, Sauter AJ. Ultrasound screening for congenital dysplasia of the hip in newborns: its value. J Paediatr Orthop 1988;8: 666-70.

30. Castelein RM, Sauter AJM, de Vlieger, Van Linge B. Natural history of ultrasound hip abnormalities in clinically normal newborns. J Paediatr Orthop 1992;12:423-7.

31. Hernandez RJ, Cornell RG, Hensinger RN. Ultrasound diagnosis of neonatal congenital dislocation of the hip: a decision analysis assessment. J Bone Joint Surg [Br] 1994;76-B:539-43. 
32. Clarke NMP, Clegg J, Al-Chalabi AN. Ultrasound screening of hips at risk for $\mathrm{CDH}$ : failure to reduce the incidence of late cases. $J$ Bone Joint Surg [Br] 1989;71-B:9-12.

33. Godward S, Dezateux C. Surgery for congenital dislocation of the hip in the UK as a measure of outcome of screening. Lancet 1998;351: 1149-52.

34. Mckee L. Screening babies for hip dislocations is not effective. $\mathrm{Br}$ Med J 1998;346:1265.

35. Jones DA, Beynon D, Littlepage BNC. Audit of an official recommendation on screening for congenital dislocation of the hip. $\mathrm{Br} \mathrm{Med}$ J 1991;302:1435-6.
36. Tredwell SJ. Neonatal screening for hip joint instability: its clinical and economic relevance. Clin Orthop 1992;281:63-8.

37. Hart CR. Theory and its application. In: Hart CR, Burke P, eds. Screening and surveillance in general practice. Churchill Livingstone, 1992:15-23.

38. Lancet: Editorial. Screening for congenital hip dysplasia. Lancet 1991; 337:947-8.

39. Paton CR. The economics of screening. In: Hart CR, Burke P, eds. Screening and surveillance in general practice. Churchill Livingstone, 1992:25-33. 